\title{
Interleukin 4 Suppresses the Spontaneous Growth of Chronic Myelomonocytic Leukemia Cells
}

Koichi Akashi, Tsunefumi Shibuya, Mine Harada, Yasushi Takamatsu, Naokuni Uike,* Tetsuya Eto, Yoshiyuki Niho First Department of Internal Medicine, Faculty of Medicine, Kyushu University, 3-1-1 Maidashi, Higashi-Ku, Fukuoka 812, Japan; and ${ }^{*}$ Kyushu Cancer Center, 3-1-1 Nodame, Minami-Ku, Fukuoka 815, Japan

\begin{abstract}
We studied the effects of IL-4 on the spontaneous proliferation of chronic myelomonocytic leukemia (CMMoL) cells in vitro. IL-4 (100 U/ml) suppressed the spontaneous DNA synthesis by $\sim 50 \%$ in 5 of 8 cases examined. IL $-4(100 \mathrm{U} / \mathrm{ml})$ also inhibited the spontaneous colony formation by CMMoL cells in a methylcellulose culture by 50-97\% in all of the 10 cases in which spontaneous colonies were formed. This IL-4-mediated suppression of the growth of CMMoL cells was completely abolished by the addition of anti-IL-4 neutralizing antibodies. The spontaneous CMMoL colonies were substantially suppressed by the addition of either anti-IL-6 or anti-granulocyte/ macrophage colony-stimulating factor (GM-CSF) antibodies to the colony assay system: the addition of both anti-IL-6 and anti-GM-CSF antibodies resulted in $>80 \%$ inhibition of the colony formation by CMMoL cells. On the other hand, none of anti-IL-1- $\beta$, anti-granulocyte-CSF, anti-macrophage-CSF, or anti-tumor necrosis factor- $\alpha$ antibodies affected the CMMoL colony formation. In the supernatants from 24-h cultures of CMMoL cells, high levels of IL-6 and GM-CSF were demonstrated in 9 of 9 and 2 of 9 cases examined, respectively. IL-4 $(100 \mathrm{U} / \mathrm{ml})$ almost completely inhibited the secretion of $\mathrm{IL-6}$ and GM-CSF by CMMoL cells. These observations suggest that IL-4 suppresses the spontaneous proliferation of CMMoL cells by inhibiting their production of IL-6 and/or GM-CSF, both of which could act in vitro as an autocrine growth factor for CMMoL cells. (J. Clin. Invest. 1991. 88:223-230.) Key words: chronic myelomonocytic leukemia • interleukin $4 \cdot$ inhibition
\end{abstract}

\section{Introduction}

IL-4 is a T lymphocyte-derived cytokine with a variety of biologic properties. Originally being described as a cofactor for the proliferation of B cells (1), this glycoprotein also binds to receptors on hemopoietic stem cells (2), T lymphocytes, mast cells, and monocytes/macrophages (3), and shows various biological activities. In normal hemopoiesis, IL-4 exerts significant stimulatory effects on multilineage progenitors (colonyforming unit-granulocyte/erythroid/macrophage/megakaryocyte [CFU-GEMM]) (4), and synergistically supports the growth of burst-forming unit-erythroid (BFU-E), colony-forming unit-granulocyte/macrophage (CFU-GM) and CFU-

Address correspondence and reprint requests to Dr. Koichi Akashi, First Department of Internal Medicine, Faculty of Medicine, Kyushu University, 3-3-1 Maidashi, Higashi-ku, Fukuoka, Japan.

Received for publication 19 December 1990.

J. Clin. Invest.

(c) The American Society for Clinical Investigation, Inc.

0021-9738/91/07/0223/08 $\$ 2.00$

Volume 88, July 1991, 223-230
GEMM with erythropoietin (Epo), G-CSF or IL-6 $(5,6)$. On the other hand, IL-4 is known to inhibit the growth of M-CSF or GM-CSF-dependent human macrophage progenitors (CFU-M) (7) and IL-3-dependent BFU-E (8). Recently, it has been demonstrated that IL -4 exerts suppressive effects on the factor-dependent leukemic blast colony formation in certain cases of acute myelogenous leukemia $(\operatorname{AML})^{1}(9,10)$.

IL-4 is also known to act negatively on cytokine synthesis from human monocytes; IL-4 was found to be able to suppress the production of TNF- $\alpha$, IL-1- $\beta$ and IL- 6 by lipopolysaccharide- and/or gamma-interferon-stimulated normal human monocytes (11-14). This suppression was demonstrated to occur at the level of transcription (11-13).

Chronic myelomonocytic leukemia (CMMoL) is a peculiar form of myeloproliferative disorders characterized by the preferential proliferation of monocytes $(15,16)$. In contrast to cells from chronic myelogenous leukemia, which rarely form colonies without an exogenous colony-stimulating factor, $\mathrm{CMMoL}$ cells possess the capability of spontaneous colony formation in a semisolid medium (17-19). Monocytes/macrophages have been shown to produce a variety of cytokines including IL-1, IL-6, G-CSF (20), GM-CSF (21), M-CSF (22), and TNF- $\alpha$. Accordingly, an autocrine growth mechanism supported by monokines released from CMMoL cells in association with monocytoid differentiation is suggested, as has indeed been previously demonstrated in certain cases with acute myelogenous leukemia (23).

These evidences led us to investigate the possibility of a negative regulatory role of IL-4 in the autocrine growth mechanism of CMMoL cells. In this paper, we demonstrate the negative regulatory effects of IL-4 on the spontaneous growth of CMMoL cells, and present the evidence that IL-4 exerts its inhibitory effect through the suppression of IL-6 and/or GMCSF production, both of which act as an autocrine growth factor of CMMoL cells in vitro.

\section{Methods}

Patients. Patients' profiles are shown in Table I. All of the nine CMMoL patients studied fulfilled the criteria for a diagnosis of CMMoL based on the report of the French-American-British cooperative group (15). None of them had any $\mathrm{Ph}^{1}$ chromosomes. A proportion of blast cells exceeding $5 \%$ in the peripheral blood or $20 \%$ of nucleated cells in the bone marrow was considered to reflect the acute phase of the disease (18). Cases $1 a, 2 a, 4,6,7$, and 9 had not received any chemotherapy at the time of sampling. In the remaining cases, chemotherapeutic regimens including low dose aclarubicin (24) or low dose cytosine arabinoside (25) had been administered because of uncontrollable leukocytosis, but all of these cases showed stable or increasing white blood cell counts and no evidence of infection at the time of sampling.

1. Abbreviations used in this paper: AML, acute myelogenous leukemia; CMMoL, chronic myelomonocytic leukemia. 


\begin{tabular}{|c|c|c|c|c|c|c|c|c|c|}
\hline \multirow{2}{*}{$\begin{array}{l}\text { Case } \\
\text { No. }\end{array}$} & \multirow{2}{*}{$\begin{array}{l}\text { Age/ } \\
\text { Sex }\end{array}$} & \multicolumn{5}{|c|}{ Peripheral blood* } & \multirow[b]{2}{*}{ Karyotypes } & \multirow{2}{*}{$\begin{array}{l}\text { Sampling time } \\
\text { from diagnosis }\end{array}$} & \multirow{2}{*}{$\begin{array}{l}\text { Clinical } \\
\text { phase }^{t}\end{array}$} \\
\hline & & WBC & Mo & Bl & $\mathrm{Hb}$ & Plt & & & \\
\hline & & & & & & & & mo & \\
\hline $1 \mathrm{a}$ & $49 / \mathrm{F}$ & 11.6 & 38 & 0 & 6.2 & 124 & $46 \mathrm{XX}$ & $<1$ & Chronic \\
\hline $1 b$ & & 112.6 & 62 & 4 & 7.6 & 55 & $46 X X$ & 11 & Acute \\
\hline $2 a$ & $83 / \mathrm{M}$ & 36.4 & 15 & 4 & 6.7 & 50 & $46 X Y$ & $<1$ & Chronic \\
\hline $2 b$ & & 156.6 & 5 & 62 & 5.6 & 35 & $46 X Y$ & 12 & Acute \\
\hline 3 & $36 / \mathrm{F}$ & 157.5 & 24 & 21 & 7.5 & 16 & $46 X X, i(17 q)$ & 9 & Acute \\
\hline 4 & $66 / F$ & 36.2 & 50 & 0 & 8.2 & 144 & $46 \mathrm{XX}$ & $<1$ & Chronic \\
\hline 5 & $60 / \mathrm{M}$ & 32.0 & 24 & 4 & 7.8 & 20 & $45, X Y,-7$ & 6 & Chronic \\
\hline 6 & $82 / \mathrm{M}$ & 64.0 & 34 & 12 & 5.8 & 24 & $46 X Y$ & 8 & Acute \\
\hline 7 & $68 / \mathrm{F}$ & 18.2 & 36 & 3 & 8.2 & 23 & $46 \mathrm{XX}$ & $<1$ & Chronic \\
\hline 8 & $72 / \mathrm{M}$ & 15.7 & 33 & 16 & 8.1 & 25 & $\begin{array}{l}42 X Y,-7,-16,-17 \\
-18,5 q-, 15 p+, 21 q-\end{array}$ & 4 & Acute \\
\hline 9 & $58 / \mathrm{M}$ & 20.7 & 23 & $\mathbf{0}$ & 6.5 & 45 & $46 X Y$ & $<1$ & Chronic \\
\hline
\end{tabular}

${ }^{*} H b$, hemoglobin (g/dl); $M o$, monocytes (\%); Bl, blasts (\%); WBC, white blood cells $\left(\times 10^{9} /\right.$ liter $) ; P l t$, platelets $\left(\times 10^{9} /\right.$ liter). ${ }^{\ddagger}$ Acute phase was considered when percentages of blast cells in the peripheral blood and bone marrow exceeded 5 and $20 \%$, respectively.

Preparation of cells. Heparinized peripheral blood samples were taken from the CMMoL patients listed above after obtaining an informed consent. PBMCs were separated by centrifugation on a FicollHypaque density gradient. Adherent cells were removed with a glassadhesion technique and $\mathrm{T}$ cells were depleted by using CD2-conjugated immunomagnetic beads (Dynabeads M-450; Dynal A. S., Oslo, Norway). Nonadherent, non-T PBMCs were used for the following assays. Normal monocytes were collected by leukoapheresis from two patients with acute lymphoblastic leukemia (during the first complete remission) at a recovery phase from myelosuppressive consolidation chemotherapy. Monocytes were enriched to 82 and $84 \%$, respectively, following the Ficoll-Hypaque method and $\mathrm{T}$ cell depletion. They were incubated in a tissue culture flask (Falcon 3028; Becton Dickinson, Lincoln Park, NJ) for 30 min and adherent cells were collected. Monocytes at a recovery phase from the myelosuppressive state are activated to produce various kinds of monokines (unpublished data).

DNA synthesis. DNA synthesis of CMMoL cells was evaluated by measuring $\left[{ }^{3} \mathrm{H}\right]$ thymidine $\left(\left[{ }^{3} \mathrm{H}\right] \mathrm{TdR}\right)$ incorporation. Briefly, $1 \times 10^{5}$ CMMoL cells were cultured in the presence of different concentrations of IL-4 (sp act, $1 \times 10^{8} \mathrm{U} / \mathrm{mg}$; Genzyme, Boston, MA). Cultures were run in quadruplicate in $200 \mu$ l of IMDM (Gibco Laboratories, Grand Island, NY) containing $10 \%$ FCS in a flat-bottomed 96-well microtiter plate (Falcon 3072; Becton Dickinson). After incubation for $36 \mathrm{~h}$, cultures were pulsed with $0.5 \mu \mathrm{Ci}$ of $\left[{ }^{3} \mathrm{H}\right] \mathrm{TdR}$ for $8 \mathrm{~h}$ and $\left[{ }^{3} \mathrm{H}\right] \mathrm{TdR}$ uptakes were determined by liquid scintillation counting.

Methylcellulose assay. CMMoL cells were cultured in IMDM containing $0.88 \%$ methylcellulose and $20 \%$ fetal calf serum in a $35-\mathrm{mm}$ tissue-culture dish (Lux 5221-R; Naperville, IL). $1 \times 10^{5}$ cells in $1 \mathrm{ml}$ medium containing different concentrations of $1 \mathrm{~L}-4$ were incubated under $100 \%$ humidity with $5 \% \mathrm{CO}_{2}$ in air at $37^{\circ} \mathrm{C}$ for $14 \mathrm{~d}$. Colonies consisting of $>20$ cells were counted under an inverted microscope.

Neutralizing antibodies. Rabbit polyclonal Ab against various human growth factors were used for neutralization: anti-IL-4 $\mathrm{Ab}$ (neutralizing titer [NT], $\left.4 \times 10^{6} \mathrm{U} / \mathrm{ml}\right)$; anti-IL-6 Ab (NT, $\left.1 \times 10^{4} \mathrm{U} / \mathrm{ml}\right)$; anti-GM-CSF Ab (NT, $\left.1 \times 10^{3} \mathrm{U} / \mathrm{ml}\right)$; anti-G-CSF Ab (NT, $1 \times 10^{4}$ $\mathrm{U} / \mathrm{ml}$ ); anti-IL-1- $\beta \mathrm{Ab}\left(\mathrm{NT}, 1 \times 10^{3} \mathrm{U} / \mathrm{ml}\right.$ ); and anti-TNF- $\alpha \mathrm{Ab}$ (NT, 1 $\times 10^{5} \mathrm{U} / \mathrm{ml}$ ) were purchased from Genzyme Corp., Cambridge, MA. These antibodies were specified as not showing any cross-reaction with each other. At the concentrations used in this study, none of these were toxic to cell proliferation (data not shown). For the inhibition of colony formation, antibodies were incorporated into the semisolid culture medium at the time of plating. For the neutralization of IL-4 activity, $1 \mathrm{ml}$ of IL-4 $(100 \mathrm{U} / \mathrm{ml})$ was preincubated $\left(37^{\circ} \mathrm{C}\right.$ for $\left.2 \mathrm{~h}\right)$ with $10 \mu \mathrm{l}$ of anti-IL-4 $\mathrm{Ab}$.

Cytokine assays. $2 \times 10^{6} / \mathrm{ml}$ of CMMoL cells and normal monocytes were suspended in IMDM containing 10\% FCS with or without different concentrations of IL-4, and the culture supernatants were harvested after incubation for $24 \mathrm{~h}$ at $37^{\circ} \mathrm{C}$ with $5 \% \mathrm{CO}_{2}$. Patients' plasma was obtained from 10 of 11 cases. These samples were assayed as follows: IL-6 was measured with an ELISA by using a two-step sandwich method. Briefly, a murine MAb specific for human IL-6 was attached to microtiter wells and samples were applied. After a 18-h incubation at $4^{\circ} \mathrm{C}$, a biotin-labeled murine anti-human IL-6 MAb, which could bind different epitopes on the IL- 6 from that of primary anti-IL-6 $\mathrm{MAb}$, was added. After a $1-\mathrm{h}$ incubation at $23^{\circ} \mathrm{C}$, a horseradish peroxidase-conjugated streptoavidin reagent was added, and the absorbance was measured with a microplate colorimeter. IL-1- $\beta$ and GM-CSF were assayed with an ELISA by using a human interleukin-1- $\beta$ ELISA kit (Otsuka assay; Otsuka Pharmaceutical Co. Ltd., Japan) and a human GM-CSF ELISA kit (Genzyme Corp.), respectively. G-CSF was measured by means of a radioimmunoassay. Briefly, standards and culture supernatants $(0.2 \mathrm{ml})$ were incubated with $0.1 \mathrm{ml}$ of diluted (1:100) rabbit anti-G-CSF Ab (Kirin Beer Co. Ltd., Tokyo) at $4^{\circ} \mathrm{C}$ for $48 \mathrm{~h} .0 .1 \mathrm{ml}$ of ${ }^{125} \mathrm{I}$-labeled rhG-CSF $\left(1 \times 10^{5} \mathrm{cpm} / \mathrm{ml}\right)$ was added and incubated for $24 \mathrm{~h}$ at $4^{\circ} \mathrm{C}$. Samples were mixed with $0.1 \mathrm{ml}$ of diluted (1:100) rabbit serum and $0.1 \mathrm{ml}$ of diluted $(1: 20)$ anti-rabbit goat antibodies. After $30 \mathrm{~min}$ of incubation at room temperature, bound and free G-CSF were separated by centrifugation, and their radioactivity was measured with a gamma counter. TNF- $\alpha$ was measured with a TNF- $\alpha$ RIA kit (Ire-Medgenix, Fleurus, Belgium).

\section{Results}

Effect of IL-4 on DNA synthesis of CMMoL cells. Table II shows the inhibitory effect of IL-4 on the spontaneous DNA synthesis of CMMoL cells. IL-4 significantly suppressed the spontaneous DNA synthesis of CMMoL cells in five of eight cases examined in a dose-dependent manner. This inhibition reached a plateau when the addition of IL-4 reached a level of 
Table II. Effect of IL-4 on Spontaneous DNA Synthesis

\begin{tabular}{lrrrcccc}
\hline & \multicolumn{6}{c}{ ['H]Thymidine incorporation (cpm) } \\
\cline { 2 - 7 } Case & & \multicolumn{5}{c}{ IL-4 Concentration } \\
\cline { 2 - 7 } No. & Control & \multicolumn{1}{c}{1} & 10 & 100 & 500 & $100+$ Ab $^{*}$ \\
\hline & & & & $U / m l$ & & \\
& & & & & \\
$1 \mathrm{a}$ & 11,248 & 11,564 & 9,708 & $5,816^{*}$ & $5,780^{*}$ & 10,045 \\
$2 \mathrm{a}$ & 26,780 & 25,685 & 18,741 & $14,467^{*}$ & $\mathrm{ND}$ & 24,800 \\
3 & 6,088 & 6,645 & 6,867 & 4,403 & 3,836 & ND \\
4 & 23,889 & 25,678 & 20,168 & $12,517^{*}$ & $11,934^{*}$ & 23,812 \\
5 & 1,476 & 1,588 & 1,443 & 1,377 & 1,347 & ND \\
6 & 8,289 & 9,240 & 6,832 & $5,689^{*}$ & $5,537^{*}$ & ND \\
7 & 2,882 & 2,945 & 3,324 & 2,689 & ND & 2,879 \\
8 & 4,822 & ND & 4,792 & $1,211^{*}$ & ND & ND \\
& & & & & & \\
\hline
\end{tabular}

Results are shown as the mean value in quadruplicate cultures $\left({ }^{*} P\right.$ $<0.05$ ). ND, not done. ${ }^{\ddagger}$ Anti-IL-4 antibody was added.

$100 \mathrm{U} / \mathrm{ml}$, and the maximum inhibition was $\sim 50 \%$. The inhibition could be abolished by the addition of anti-IL- $4 \mathrm{Ab}$.

Effect of IL-4 on colony formation of CMMoL cells. IL-4 also suppressed the spontaneous 14-d colony formation of CMMoL cells. The results are shown in Table III. The dose-dependent inhibition was observed in all of the seven patients who showed spontaneous colony formation, and reached a plateau when IL-4 was added at a concentration of $100 \mathrm{U} / \mathrm{ml}$. The maximum inhibition was 50 to $97 \%$ of the total colony formation. The appearance of spontaneous CMMoL colonies and IL-4-mediated inhibition of colony formation is illustrated in Fig. 1. This inhibitory action of IL-4 was completely abolished by the addition of anti-IL- 4 antibodies to the culture system.

Differential countings of colony types in cases 4 and 7 revealed that the IL-4-induced suppression was observed in all types of colonies formed: granulocyte colony-forming cells (GCFC), GM-CFC and M-CFC (Fig. 2).
Effect of neutralizing antibodies on colony formation of CMMoL cells. To investigate the autocrine mechanism of CMMoL cell growth, we added neutralizing antibodies against various cytokines to the methylucellulose assay system. The addition of anti-IL-6 or anti-GM-CSF antibodies resulted in a significant reduction of spontaneous colony formation in all and in seven of the eight cases examined, respectively (Table IV). Furthermore, the addition of both anti-IL-6 and anti-GMCSF Abs resulted in $>80 \%$ suppression of colony numbers in all of four cases studied. However, neither anti-G-CSF, anti-IL$1-\beta$, anti-M-CSF, nor anti-TNF- $\alpha$ showed a significant effect on the colony formation in any cases examined.

Effect of IL-4 on cytokine production by CMMoL cells. We then analyzed the effect of IL-4 on the production of monokines by CMMoL cells. The results are shown in Table V. CMMoL cells produced extremely high levels of IL-6 in all of the nine cases examined, compared with those produced by normal monocytes, although the concentrations varied from case to case. IL- 4 inhibited this IL- 6 production by CMMoL cells in a dose-dependent manner (Fig. 3), and this inhibition reached a plateau at a concentration of $100 \mathrm{U} / \mathrm{ml}$. A detectable level of GM-CSF was also observed in two cases (cases $1 a$ and 5). In these two cases, the production of GM-CSF was also completely inhibited with the addition of $100 \mathrm{U} / \mathrm{ml}$ of IL-4 (Table V and Fig. 4).

The spontaneous production of IL-1- $\beta$, G-CSF, and TNF- $\alpha$ was also observed in seven of eight, three of nine and eight of eight cases examined, respectively. Levels of these monokines were almost similar to those produced by normal monocytes, except for G-CSF in cases $1 a$ and 7, and TNF- $\alpha$ in cases $1 a$ and 6 , in which more than fivefold amplified production compared with normal monocytes was observed. The addition of 100 $\mathrm{U} / \mathrm{ml}$ of IL-4 also suppressed the production of all of these monokines.

Concentrations of plasma IL-6 and GM-CSF in CMMoL patients. Elevation of plasma IL-6 was observed in all the samples collected from six cases where the WBC counts were elevated to more than $40 \times 10^{9} /$ liter. The results are shown in Fig. 5. A significant correlation between plasma IL-6 concentration

Table III. Effects of IL-4 on Spontaneous Colony Formation

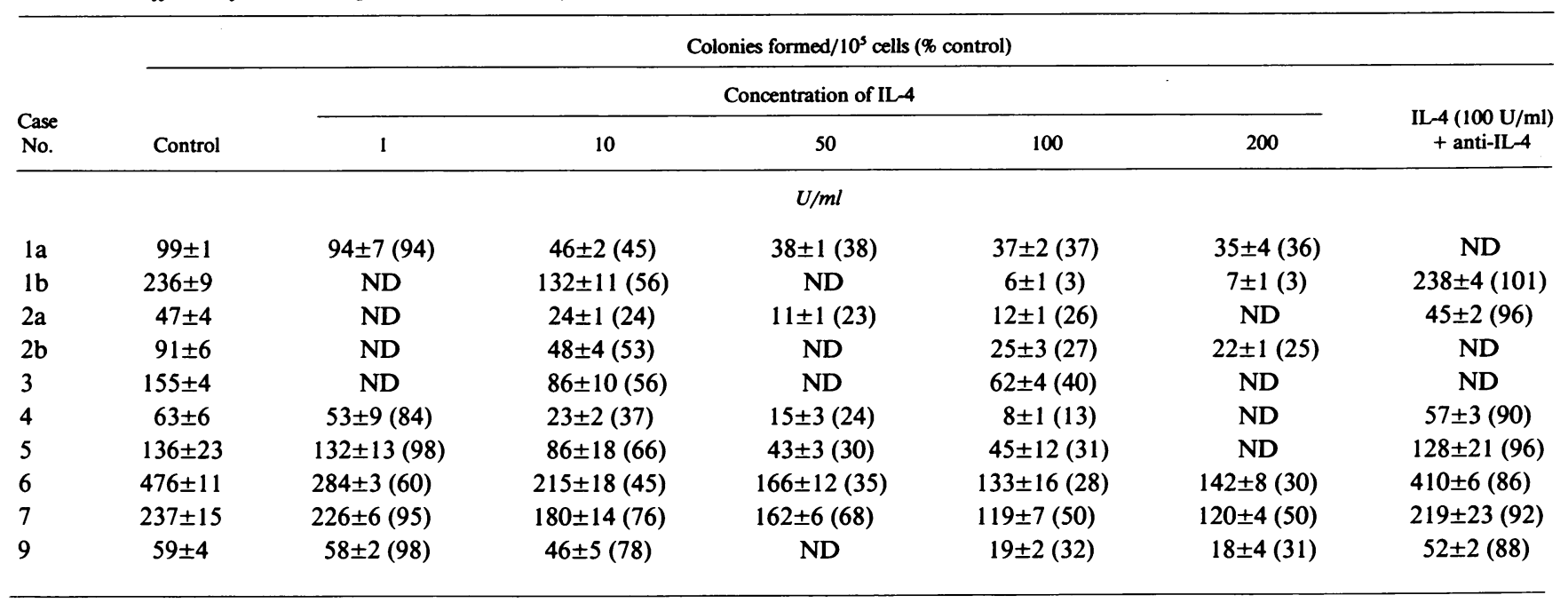

Results are shown as the mean \pm SD in triplicate cultures. Spontaneous colony formation was not observed in case 8. 

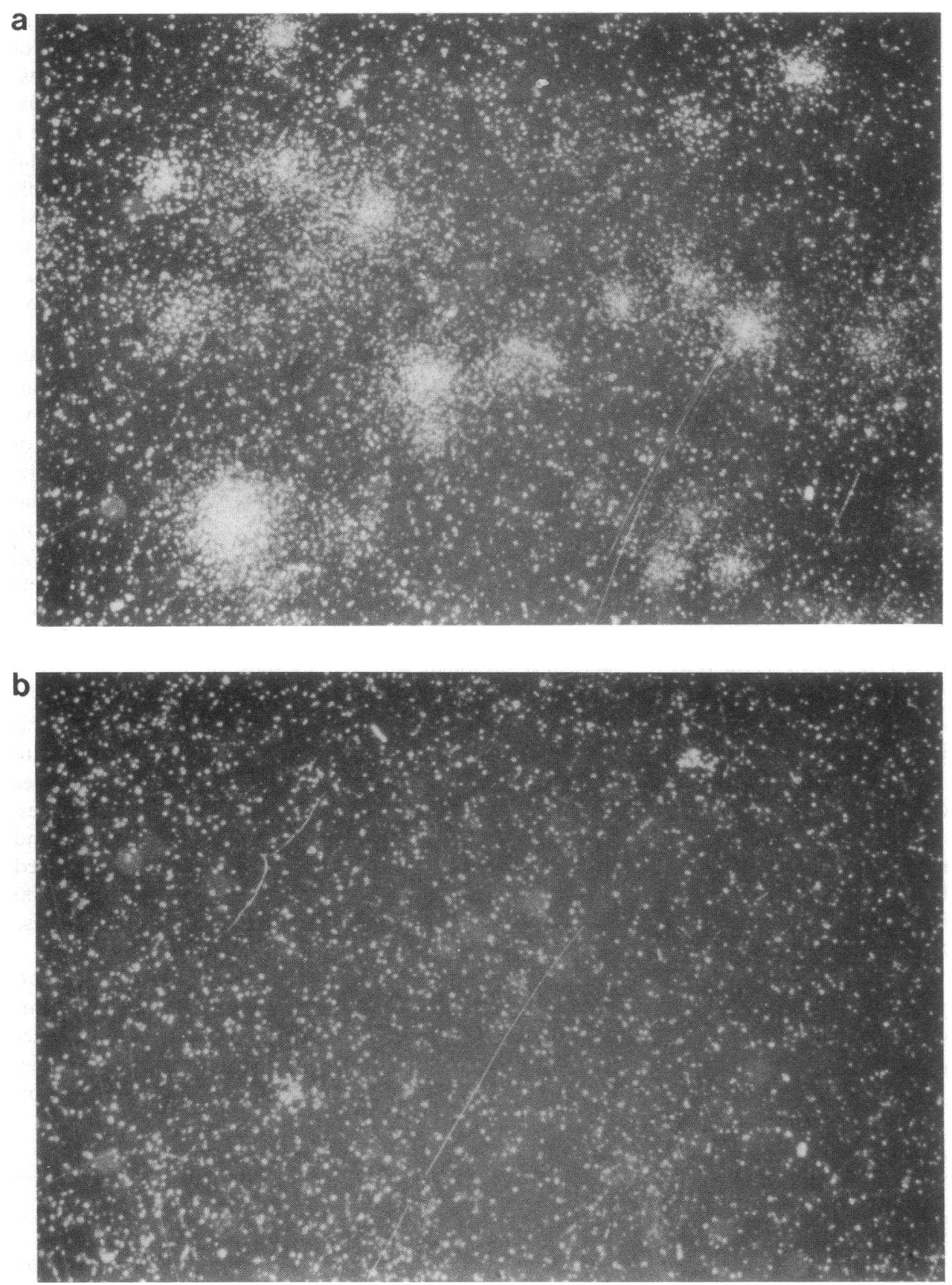

Figure 1. The appearance of 14-d spontaneous CMMoL colonies in case $1 b$ obtained by a methylcellulose assay $(\times 20)(a)$. The addition of IL-4 (100 U/ml) almost completely inhibited the CMMoL colony growth $(\times 20)(b)$. This inhibition of spontaneous CMMoL colony formation by IL- 4 was completely prevented by the pretreatment of IL-4 with anti-IL-4 Ab (c). and WBC counts was observed $(r=0.892)$. Detectable levels of GM-CSF were seen in only three of the ten cases examined: $300 \mathrm{pg} / \mathrm{ml}$ in case $1 a ; 480 \mathrm{pg} / \mathrm{ml}$ in case $2 a$, and $88 \mathrm{pg} / \mathrm{ml}$ in case 5 .

\section{Discussion}

This study clearly indicates that IL-4 can suppress both the spontaneous colony growth and DNA synthesis of CMMoL cells from acute and chronic phases of the disease. This suppression was observed in all types of spontaneous CMMoL colonies including CFU-G, CFU-GM, and CFU-M, suggesting that the inhibitory action of IL-4 is not limited to CFU-M. This is in contrast to the observations in the case of normal hemopoiesis (7).

The addition of antibodies against various growth factors revealed that anti-IL- 6 and anti-GM-CSF Abs could suppress spontaneous CMMoL colony formation, while neither anti-GCSF, anti-IL-1- $\beta$, nor anti-M-CSF Ab was able to do this. The combination of anti-IL-6 and anti-GM-CSF Abs inhibited $>80 \%$ of the colony formation. Therefore, in agreement with a recent report by Everson et al. (19), it is suggested that IL-6 and GM-CSF play an important role as an autocrine growth factor for CMMoL cells.

The measurement of monokines in the 24-h culture supernatant revealed that $\mathrm{CMMoL}$ cells produced extremely high 


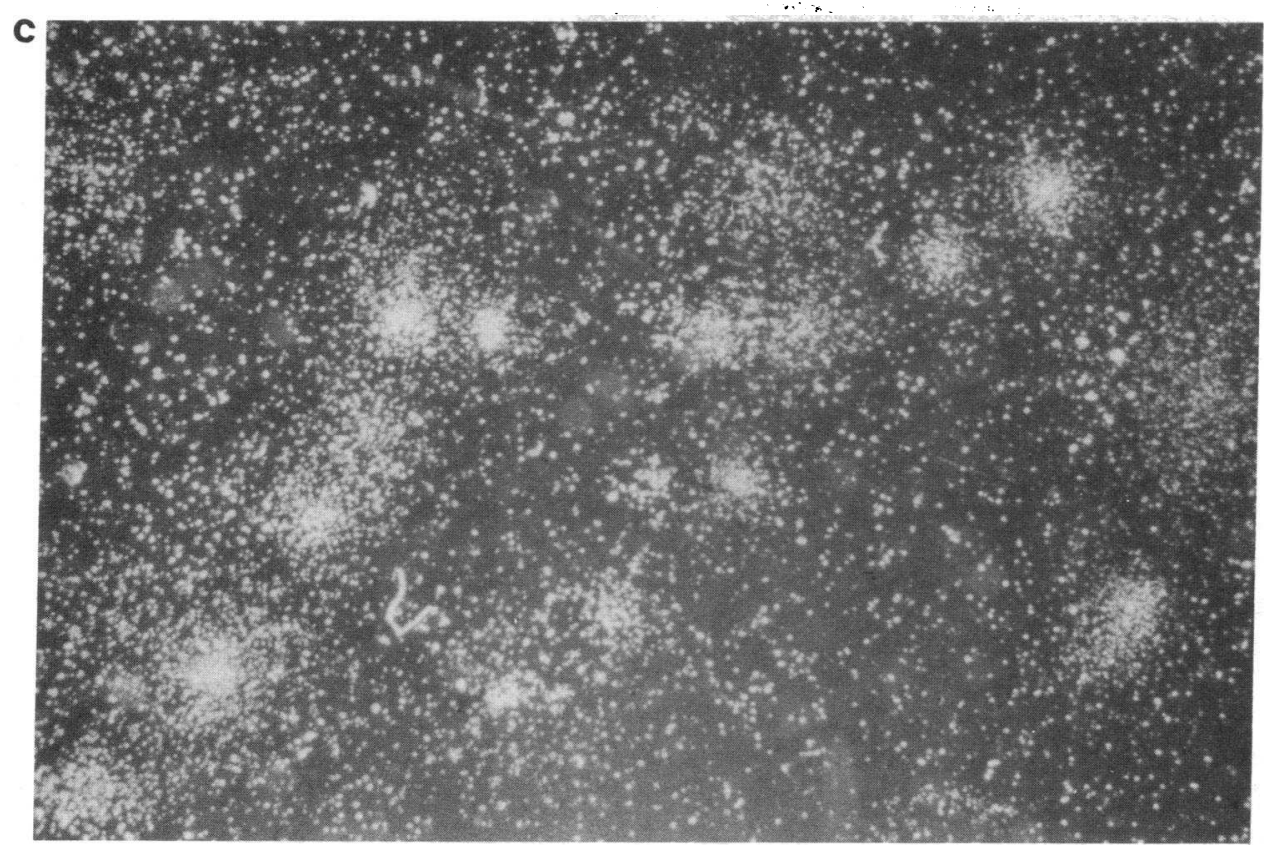

Figure 1 (Continued)

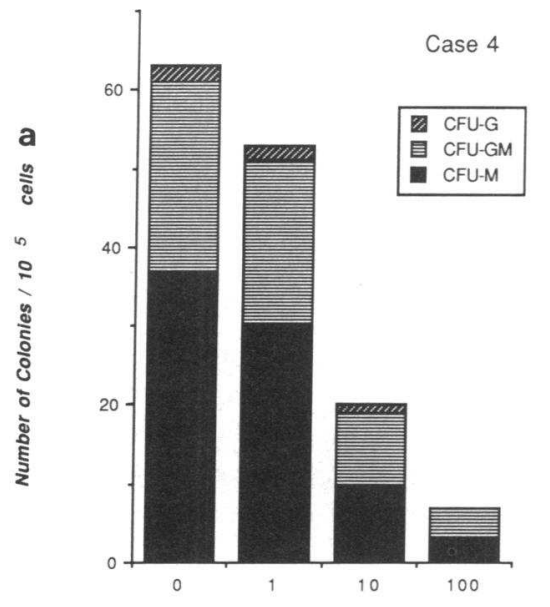

Concentration of $L L-4(U / m L)$

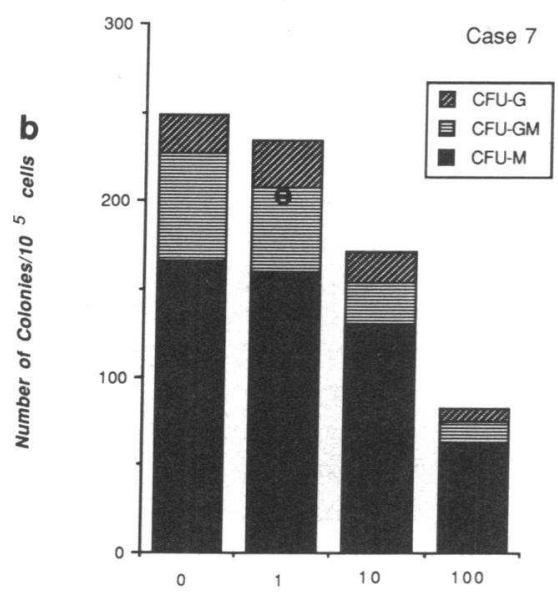

Concentration of $1 \mathrm{~L}-4 \quad(\mathrm{U} / \mathrm{m} /)$

Figure 2. Results of the differential colony counting in case $4(a)$ and in case $7(b)$. concentrations of IL- 6 and GM-CSF compared with those produced by normal monocytes. This indicates a pathologicallyamplified production of IL-6 and GM-CSF in CMMoL cells. IL-4 almost completely inhibited the spontaneous production of IL- 6 and GM-CSF by CMMoL cells. Accordingly, IL-4 probably exerts its inhibitory action through inhibiting the production of autocrine growth factors, IL-6 and GM-CSF in vitro. However, anti-GM-CSF Ab suppressed the in vitro colony formation in three CMMoL cases in which detectable GM-CSF

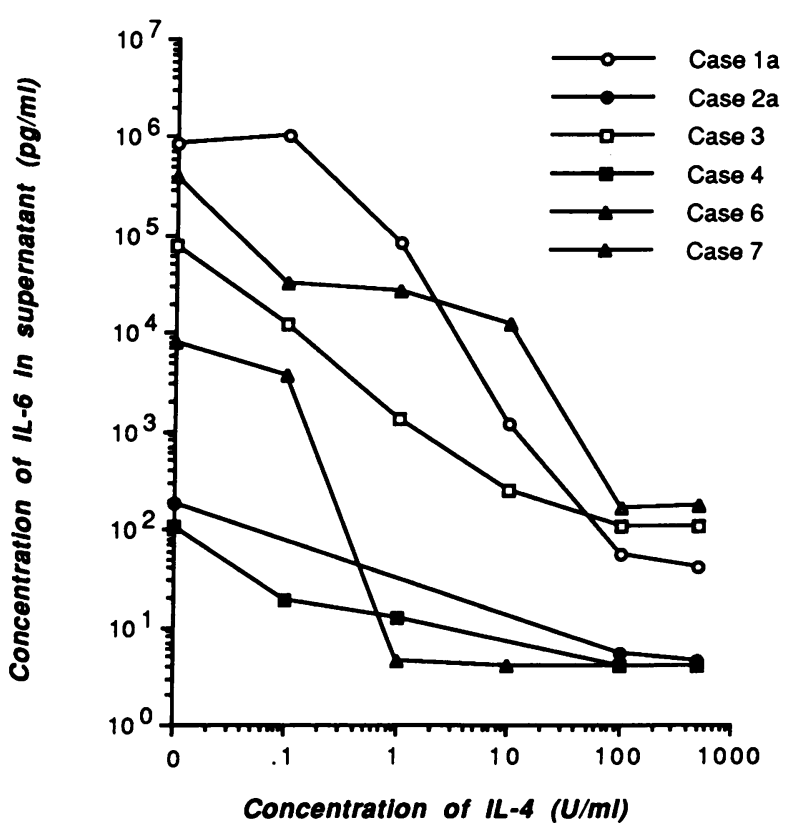

Figure 3. Dose-dependent relationships between IL-6 levels in supernatants from 24-h cultures of CMMoL cells and IL-4 concentrations added. IL-4 showed the significant inhibition of IL- 6 production by CMMoL cells in a dose-dependent manner in all six cases examined. 
Table IV. Effects of Neutralizing Antibodies on Spontaneous Colony Formation

\begin{tabular}{|c|c|c|c|c|c|c|c|}
\hline \multirow[b]{2}{*}{$\begin{array}{l}\text { Case } \\
\text { No. }\end{array}$} & \multicolumn{7}{|c|}{ Colonies formed $/ 10^{5}$ cells ( $\%$ control) } \\
\hline & Control & Anti-IL-6 & Anti-GM-CSF & $\begin{array}{c}\text { Anti-GM-CSF } \\
+ \text { anti-IL-6 }\end{array}$ & Anti-IL-1 $\beta$ & Anti-G-CSF & Anti-M-CSF \\
\hline $1 \mathrm{a}$ & $99 \pm 1$ & $45 \pm 8(46)$ & $16 \pm 4(16)$ & $9 \pm 1(9)$ & $92 \pm 1(93)$ & $88 \pm 8(89)$ & $96 \pm 7(93)$ \\
\hline $1 b$ & $236 \pm 9$ & $97 \pm 5(41)$ & $117 \pm 5(50)$ & $42 \pm 8(18)$ & $208 \pm 7(88)$ & $238 \pm 32(101)$ & $224 \pm 23(94)$ \\
\hline $2 a$ & $47 \pm 4$ & $36 \pm 1(77)$ & $7 \pm 1(15)$ & ND & $44 \pm 9(90)$ & $38 \pm 9(81)$ & $46 \pm 6(98)$ \\
\hline $2 b$ & $91 \pm 6$ & $24 \pm 3(26)$ & ND & ND & $84 \pm 4(92)$ & $80 \pm 10(88)$ & ND \\
\hline 5 & $136 \pm 23$ & $45 \pm 8(31)$ & $130 \pm 25(97)$ & $21 \pm 3(15)$ & $130 \pm 13(97)$ & $132 \pm 13(97)$ & $139 \pm 32(102)$ \\
\hline 6 & $476 \pm 11$ & $260 \pm 15(55)$ & $196 \pm 15(42)$ & ND & $446 \pm 22(94)$ & $444 \pm 34(93)$ & $479 \pm 34(101)$ \\
\hline 7 & $237 \pm 15$ & $160 \pm 20(68)$ & $180 \pm 12(76)$ & ND & $234 \pm 14(99)$ & $221 \pm 16(93)$ & $247 \pm 13(104)$ \\
\hline 9 & $59 \pm 4$ & $30 \pm 4(51)$ & $47 \pm 2(80)$ & $12 \pm 4(20)$ & $59 \pm 5(100)$ & $52 \pm 2(88)$ & $56 \pm 2(96)$ \\
\hline
\end{tabular}

Results are shown as the mean $\pm \mathrm{SD}$ in triplicate cultures. Neutralizing antibodies were added at initiation of culture at the following final dilutions: anti-IL-6 and anti-M-CSF, 1:50; anti-GM-CSF, anti-G-CSF, anti-IL-1 $\beta$, and anti-TNF $\alpha, 1: 100$.

was not demonstrated in culture supernatants: case 6 with antiGM-CSF $\mathrm{Ab}$ alone, and cases 5 and 9 with a combination of anti-GM-CSF and anti-IL-6 Abs. This discrepancy may be due to the in vitro uptake of GM-CSF by CMMoL cells, and/or to the relative insensitivity of an ELISA assay for GM-CSF. TNF$\alpha$, which is known to be a suppressor of hematopoietic progenitors, is not actively involved in this inhibitory action of IL-4, because TNF- $\alpha$ production by CMMoL cells was also suppressed by the addition of IL-4.

IL-6 was demonstrated to synergistically support the growth of primitive hematopietic progenitors including CFUGM, BFU-E, and CFU-GEMM with IL-3 (26), and to stimulate the formation of CFU-M in the presence of M-CSF (27). Caracciolo et al. reported that IL-6 was able to enhance the growth of neutrophilic-granulocytic colonies in the presence of GM-CSF, and that IL-6 alone could induce granulocytic differentiation in an AML cell line (28). In addition, in some AML cases, IL-6 and GM-CSF could stimulate proliferation of
AML-CFU (29-31), and IL-6 was shown to synergize with GM-CSF in the stimulation of AML-CFU $(29,32)$. On the basis of these observations, IL-6 and GM-CSF would probably take part in the autocrine growth mechanism of CMMoL depending on their growth-stimulating and differentiation-promoting activities.

It is of major concern whether any relationship exists between the spontaneous in vitro proliferation of $\mathrm{CMMoL}$ cells and the in vivo biology of the disease. Several reports have demonstrated the expression of IL-1, IL-6, G-CSF, GM-CSF, and TNF by AML cells $(33,34)$. IL-6, G-CSF, and GM-CSF can support the growth of AML-CFU, and the additional IL-1 or TNF synergistically enhances the factor-dependent AMLCFU growth in some cases $(34,35)$. From these observations, it is implied that some of these factors may be actively involved in the autocrine growth of AML cells. However, Baer et al. suggested the possibility that the expression of these cytokines by AML cells may be an artifact of in vitro culture (36).

Table V. Effect of IL-4 on Spontaneous Production of Cytokines

\begin{tabular}{|c|c|c|c|c|c|c|c|c|c|c|}
\hline \multirow{2}{*}{$\begin{array}{l}\text { Case } \\
\text { No. }\end{array}$} & \multicolumn{2}{|c|}{$\mathrm{IL}-6(\mathrm{pg} / \mathrm{ml})$} & \multicolumn{2}{|c|}{ GM-CSF (pg/ml) } & \multicolumn{2}{|c|}{$\frac{\text { IL-1 } \beta(\mathrm{pg} / \mathrm{ml})}{\mathrm{IL}-4 \text { added }}$} & \multicolumn{2}{|c|}{$\mathrm{G}-\mathrm{CSF}(\mathrm{pg} / \mathrm{ml})$} & \multicolumn{2}{|c|}{ TNF- $\alpha(\mathrm{pg} / \mathrm{ml})$} \\
\hline & 0 & 100 & 0 & 100 & 0 & 100 & 0 & 100 & $\mathbf{0}$ & 100 \\
\hline & \multicolumn{10}{|c|}{$U / m l$} \\
\hline 1a & 860,000 & 185 & 1,180 & 14 & 667 & 219 & 6,700 & 2,700 & 3,900 & 1,690 \\
\hline $2 a$ & 185 & $<4$ & $<4$ & $<4$ & 96 & 37 & 690 & $<100$ & 1,080 & 134 \\
\hline 3 & 80,000 & 109 & $<4$ & $<4$ & 70 & 27 & $<100$ & $<100$ & 625 & 504 \\
\hline 4 & 106 & 9 & $<4$ & $<4$ & 101 & 66 & $<100$ & $<100$ & 1,790 & 1,140 \\
\hline 5 & 1,900 & 12 & 62 & $<4$ & 40 & 40 & $<100$ & $<100$ & 72 & 31 \\
\hline 6 & 383,000 & 1,600 & $<4$ & $<4$ & 187 & 180 & $<100$ & $<100$ & 4,050 & 2,410 \\
\hline 7 & 8,000 & $<4$ & $<4$ & $<4$ & 34 & 17 & 2,100 & $<100$ & 545 & 217 \\
\hline 8 & 620 & $<4$ & $<4$ & $<4$ & $<20$ & $<20$ & $<100$ & $<100$ & 32 & $<15$ \\
\hline 9 & 12,300 & 953 & $<4$ & $<4$ & ND & ND & $<100$ & $<100$ & ND & ND \\
\hline \multicolumn{11}{|c|}{ Normal monocytes } \\
\hline Experiment 1 & 39.8 & 10.0 & $<4$ & $<4$ & ND & ND & 172 & $<100$ & 628 & 240 \\
\hline Experiment 2 & 20.9 & 4.8 & $<4$ & $<4$ & 200 & 71 & $<100$ & $<100$ & 637 & 336 \\
\hline
\end{tabular}

24-h culture supernatants obtained by suspension culture of $2 \times 10^{6} \mathrm{CMMoL}$ cells was evaluated. 


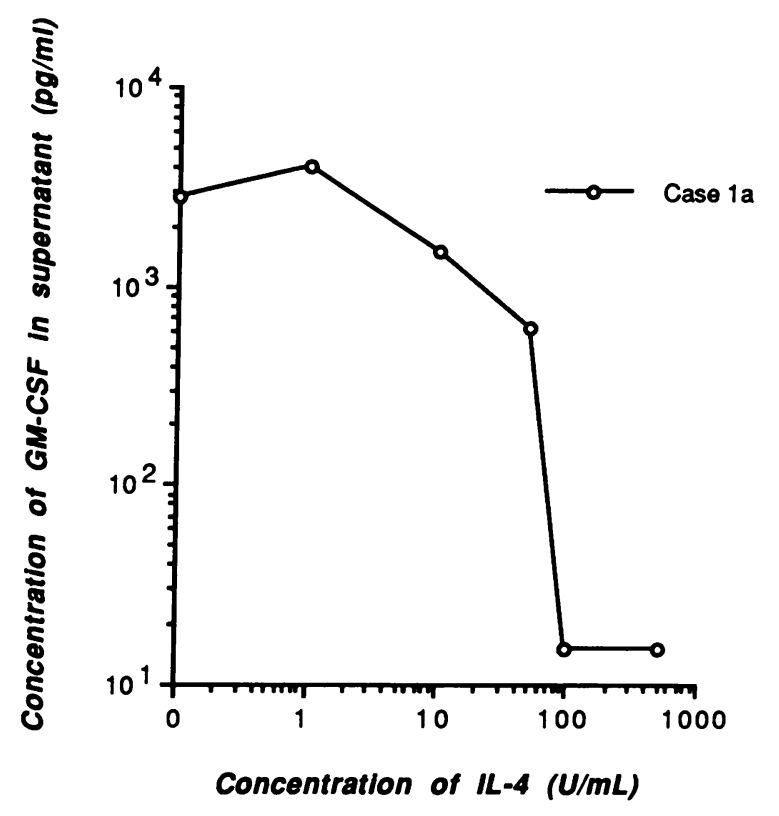

Figure 4. Dose-dependent relationships between GM-CSF levels in supernatants from 24-h cultures of CMMoL cells in case $1 a$ and IL-4 concentrations added. IL-4 showed significant inhibition of GM-CSF production by CMMoL cells in a dose-dependent manner.

In addition to high levels of IL-6 in the culture supernatant of CMMoL cells, we could also detect considerable levels of IL-6 in uncultured CMMoL cell lysates in all the six cases examined (cases $1 a, 2 a, 5,6,7$, and 9) (data not shown). Furthermore, a positive relationship between plasma IL-6 levels and WBC counts was observed in CMMoL cases, whereas detectable levels $(>4 \mathrm{pg} / \mathrm{ml})$ of IL-6 were not observed in five normal individuals (data not shown). These results indicate that IL-6 plays an important role in the in vivo proliferation of CMMoL cells. On the other hand, detectable levels of GM-CSF were demonstrated in 24-h culture supernatants from two CMMoL cases (cases $1 a$ and 5) in which GM-CSF could also be detected in uncultured cell lysates (data not shown); the elevation of plasma GM-CSF levels was observed in both cases. From these results, it is also suggested that GM-CSF may act as an in vivo autocrine growth factor in at least a minority of CMMoL patients.

In conclusion, IL-4 suppresses the spontaneous proliferation of CMMoL cells by inhibiting their production of IL-6 and/or GM-CSF, both of which could act in vitro as an auto-

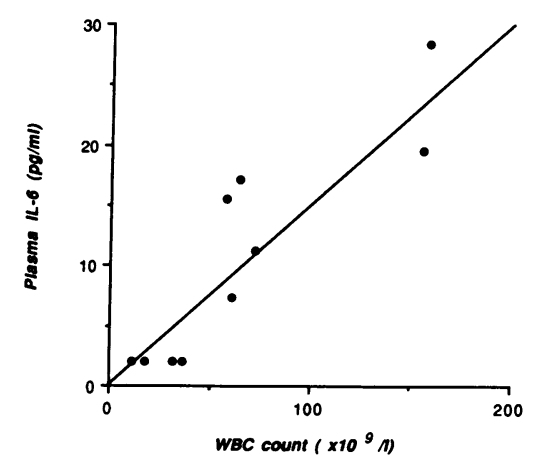

Figure 5. Correlation between plasma IL-6 levels and total WBC counts in $10 \mathrm{CMMoL}$ cases $(r=0.892 ; P$ $<0.01)$. crine growth factor for CMMoL cells. This strongly suggests that IL-4 may play an important role in the negative regulation of normal or leukemic hematopoiesis.

\section{Acknowledgements}

This work was supported in part by a Grants-in-Aid from the Ministry of Education, Science, and Culture (2670284 and 2151017), and the Mitui Life Welfare Foundation.

\section{References}

1. Howard, M., J. Farrar, M. Hifiker, B. Johnson, K. Takatsu, T. Hamaoka, and W. E. Paul. 1982. Identification of a T cell-derived B cell growth factor distinct from interleukin 2. J. Exp. Med. 155:914-923.

2. Peschel, C., I. Green, J. Ohara, and W. E. Paul. 1987. Role of B cell stimulatory factor 1/interleukin 4 on hematopoietic progenitor cells. Blood. 70:254-263.

3. Ohara, J., and W. E. Paul. 1987. Receptors for B-cell stimulatory factor-1 expressed on cells of haematopoietic lineage. Nature (Lond.). 325:537-540.

4. Kishi, K., J. N. Ihle, D. L. Urdal, and M. Ogawa. 1989. Murine B-cell stimulatory factor-1 (BSF-1)/interleukin-4 (IL-4) is a multilineage colony-stimulating factor that acts directly on primitive hemopoietic progenitors. J. Cell. Physiol. 139:463-468.

5. Sonoda, Y., T. Okuda, S. Yokota, T. Maekawa, Y. Shizumi, H. Nishigaki, S. Misawa, H. Fujii, and T. Abe 1990. Actions of human interleukin-4/B-cell stimulatory factor-1 on proliferation and differentiation of enriched hematopoietic progenitor cells in culture. Blood. 75:1615-1621.

6. Rennick, D., J. Jackson, G. Yang, J. Widerman, F. Lee, and S. Hudak. 1989. Interleukin-6 interacts with interleukin-4 and other hematopoietic growth factors to selectively enhance the growth of megakaryocytic, erythroid, myeloid, and multipotential progenitor cells. Blood. 73:1828-1835.

7. Jansen, J. H., H. M. Wientjens, W. E. Fibbe, R. Willemze, and H. C. Kluin-Nelemans. 1989. Inhibition of human macrophage colony formation by interleukin 4. J. Exp. Med. 170:577-582.

8. Wolf, J. T. M., J. A. M. Beentjes, M. T. Esselink, J. W. Smit, and M. R Halie. 1990. Interleukin-4 suppresses the interleukin-3 dependent erythroid colony formation from normal human bone marrow cells. Br. J. Haematol. 74:246250.

9. Vellenga, E., J. T. M. DeWolf, J. A. M. Beentjes, M. T. Esselink, J. W. Smit, and M. R. Halie. 1990. Divergent effects of interleukin-4 (IL-4) on the granulocyte colony-stimulating factor and IL-3-supported myeloid colony formation from normal and leukemic bone marrow cells. Blood. 75:633-637.

10. Akashi, K., M. Harada, T. Shibuya, Y. Takamatsu, T. Teshima, and Y. Niho. 1991. Effects of interleukin 4 and interleukin 6 on the proliferation of CD34+ and CD34- blasts from acute myelogenous leukemia. Blood. In press.

11. Essner, R., K. Rhoades, W. H. Mcbridge, D. J. Norton, and J. S. Economou. 1989. IL-4 down-regulates IL-1 and TNF gene expressions in human monocytes. J. Immunol. 142:3857-3861.

12. Hart, H. P., F. G. Vitti, D. R. Burgess, G. A. Whitty, D. S. Piccoli, and J. A. Hamilton. Potential antiinflammatory effects of interleukin 4: suppression of human monocyte tumor necrosis factor-alpha, interleukin 1, and prostaglandin $\mathrm{E}_{2}$. Proc. Natl. Acad. Sci. USA. 86:3803-3807.

13. Gibbons, R., O. Martinez, M. Matli, F. Heinzel, M. Bernstein, and R. Warren. 1990. Recombinant IL-4 inhibits IL-6 synthesis by adherent peripheral blood cells in vitro. Lymphokine Res. 3:283-293.

14. Te Velde, A. A., R. J. F. Huijbens, K. Heije, J. E. De Vries, and C. G. Figdor. 1990. Interleukin-4 (IL-4) inhibits secretion of IL-1 beta, tumor necrosis factor alpha, and IL-6 by human monocytes. Blood. 76:1392-1397.

15. Zitton, R. 1976. Subacute and chronic myelomonocytic leukaemia: a distinct haematological entity. Br. J. Haematol. 32:1-7.

16. Bennett, J. M., D. Catovsky, M. T. Daniel, G. Frandrin, D. A. G. Galton, H. R. Gralnick, and C. Sultan. 1982. Proposals for the classification of the myelodysplastic syndromes. Br. J. Haematol. 51:189-199.

17. Geissler, K., W. Hinterberger, P. Bettelheim, O. Haas, and K. Lechner. 1988. Colony growth characteristics in chronic myelomonocytic leukemia. Leukemia Res. 12:373-378.

18. Yuo, A., K. Miyazono, and F. Takaku. Characterization of granulocytemacrophage colony formation in chronic myelomonocytic leukemia: a comparative study with other myelodysplastic and myeloproliferative disorders. 1990 Jpn. J. Cancer Res. 81:820-826.

19. Everson, M. P., C. B. Brown, and M. B. Lilly. 1989. Interleukin 6 and granulocyte-macrophage colony-stimulating factor are candidate growth factor for chronic myelomonocytic leukemia cells. Blood. 74:1472-1476.

20. Vellenga, E., A. Rambaldi, T. J. Ernst, G. Ostapovictz, and J. D. Griffin. 1988. Independent regulation of M-CSF and G-CSF gene expression in human monocytes. Blood. 71:1529-1532. 
21. Burgess, A. W., and D. Metcalf. 1980. The nature and action of granulocyte-macrophage colony-stimulating factors. Blood. 56:947-954.

22. Rambaldi, A., D. C. Yong, and J. D. Griffin. 1987. Expression of the M-CSF (CSF-1) gene by human monocytes. Blood. 69:1409-1413.

23. Murohashi, I., S. Tohda, T. Suzuki, K. Nagata, Y. Yamashita, and N. Nara. 1989. Autocrine growth mechanisms of the progenitors of blast cells in acute myeloblastic leukemia. Blood. 74:35-41.

24. Shibuya, T., T. Teshima, M. Harada, S. Taniguchi, T. Okamura, S. Okamura, and Y. Niho. 1990. Treatment of myelodysplastic syndrome and atypical leukemia with low-dose acrarubicin. Leukemia Res. 14:161-167.

25. Worsely, A., G. J. Mufti, J. A. Copplestone, D. G. Oscier, and T. J. Hamblin. 1986. Very-low-dose cytarabine for myelodysplastic syndromes and acute myeloid leukemia in the elderly. Lancet i. 966-967.

26. Ikebuchi, K., G. G. Wong, S. C. Clark, J. N. Ihle, and Y. Hirai. 1987. Interleukin 6 enhancement of interleukin 3-dependent proliferation of multipotential hemopoietic progenitors. Proc. Natl. Acad. Sci. USA 84:9033-9039.

27. Bot, F. J., L. V. Eijk, L. Broeders, L. A. Aarden, and B. Lowenberg. 1989. Interleukin 6 synergizes with M-CSF in the formation of manrophage colonies from purified human marrow progenitor cells. Blood. 73:435-437.

28. Caracciolo, D., S. C. Clark, and G. Rovera. 1989. Human interleukin-6 supports granulocytic differentiation of hematopoietic progenitor cells and acts synergistically with GM-CSF. Blood. 73:666-670.

29. Carlo-Stella, C., L. Mangoni, C. Almici, F. Frassoni, W. Fiers, and V. Rizzoli. 1990. Growth of CD34 ${ }^{+}$acute myeloblastic leukemia colony-forming cells in response to recombinant hematopoietic factors. Leukemia. 4:561-566.
30. Suzuki, T., T. Morio, S. Tohda, K. Nagata, Y. Yamashita, Y. Imai, N. Aoki, K. Hirashima, and N. Nara. 1990. Effects of interleukin 6 and granulocyte colony-stimulating factor on the proliferation of leukemic blast progenitors from acute myeloblastic leukemia patients. Jpn. J. Cancer Res. 81:976-986.

31. Asano, Y., T. Shibuya, S. Okamura, S. Yamaga, T. Otsuka, and Y. Niho. 1987. Effect of human recombinant granulocyte/macrophage colony-stimulating factor and native granulocyte colony-stimulating factor on clonogenic leukemic blast cells. Cancer Res. 47:5647-5648.

32. Hoang T. A. Haman, O. Concalves, G. G. Wong and S. C. Clark. 1988. Interleukin 6 enhances growth factor-dependent proliferation of the blast cells of acute myeloblastic leukemia. Blood. 72:823-828.

33. Young D., and J. Griffin. 1986. Autocrine secretion of GM-CSF in acute myeloblastic leukemia. Blood. 68:1178-1181.

34. Rodoliguez-Cimadevilla, J. C., V. Beauchemin, L. Villeneuve, F. Letendre, A. Shaw, and T. Hoang. 1990. Coordinate secretion of interleukin-1 beta and granulocyte-macrophage colony-stimulating factor by the blast cells of acute myeloblastic leukemia: role of interleukin-1 as endogeneous inducer. Blood. 76:1481-1489.

35. Salem, M., R. Delwel, I. Touw, L. A. Mahmoud, E. M. Elbasousy, and B. Lowenberg. 1990. Modulation of colony stimulating factor-(CSF) dependent growth of acute myeloid leukemia by tumor necrosis factor. Leukemia. 4:37-43.

36. Baer, M. R., C. C. Watt, and H. D. Preisler. 1988. Expression of GM-CSF, G-CSF, M-CSF and IL-1 genes in acute myelogenous leukemia cells induced by in vitro cell processing. Blood. 72:109a. (Abstr.) 346(Suppl 1). 